nounced that CUNY would take over the center-called the Bernard and Gloria Salick Center for Molecular and Cellular Biology. On 23 February, Paul Marks, recently retired president of Memorial Sloan-Kettering Cancer Center, Norma Allewell, Harvard's associate vice president for sponsored programs and technology transfer, and University of Connecticut Health Center microbiologist Mary Jane Osborn held talks with Montagnier and executives from CUNY and Queens College. They will issue a report of their recommendations this month.

It was Queens alumnus Bernard Salick, the Beverly Hills-based owner of forprofit cancer and HIV clinics, who in the fall of 1997 offered \$3 million to endow a chair for Montagnier, and an additional $\$ 1.5$ million towards the cost of a new building. These funds are being held by CUNY, and the interest from the $\$ 3$ million pays Montagnier's salary and expenses. The city of New York offered another $\$ 4.5$ million towards building costs and the state was to chip in $\$ 15$ million if Queens could raise $\$ 9$ million in matching funds. However, Queens was unable to raise any of the money and although ground was broken on the center, no facilities were built. Moreover, interim laboratory space was not ready until October last year, and Montagnier, who had engaged in collaboration agreements with hospitals in Queens and Brooklyn remembers, "the problem was I did not have a lab at that time so I could not begin any research."

But in an interview with Nature Medicine, Montagnier insisted that the \$21 million Queens College has already levied is sufficient to continue with the project, which he views as "part of a network of labs I have set up in other parts of the world," operated through his World Foundation for AIDS Research and Prevention in Paris (Nature Med. 4, 1097; 1998). Montagnier also told Nature Medicine that the Paris center is not bankrupt, and sites in Rome and the Ivory Coast are thriving.

When Queens first announced that Montagnier had been lured to their campus, local newspapers called it a "coup," whereas some HIV researchers saw it as a recipe for disaster because Montagnier's research is regarded as passé and because Queens, which is largely a teaching college, seemed an unlikely spot for a major HIV research center. Biology doctoral students throughout CUNY number 361 and there were only 56 master's degree students in biology in 1997. Queens' NIH grants are small-\$1.293 million in FY99.

But CUNY defends its choice. "Dr. Montagnier has an appointment as distinguished professor, and the procedure involves external evaluations," notes CUNY Vice Chancellor for Academic Affairs Louise Mirrer. "A very large number of them were solicited at the time and there were evaluations solicited from experts in infectious disease, in particular AIDS," she continues.

Mirrer went on to confirm that the " university is exploring other options for the center, but says Montagnier, who reaches mandatory retirement age for Institut Pasteur this year, will remain a tenured professor in the Queens biology department. "This is not exactly the deal I signed with the college in the beginning. But I'm still willing to [carry on]," says Montagnier.

Myrna Watanabe, Connecticut

\title{
Kourilsky to reform the Pasteur Institute
}

Against a backdrop of unrest over government reforms to the country's national research institutes, Philippe Kourilsky, who became director of the Pasteur Institute in January, has also put in motion changes that he hopes will modernize the country's leading biomedical research center.

Many of Kourilsky's reforms tinker with the structure of the institute, and not the science itself, but he does intend to appoint a review committee to evaluate the institute's scientific research priorities.

Kourilsky, a molecular immunologist who has worked at the Pasteur for 27 years, intends to limit the post of laboratory directors to 12 years-a step implemented in 1982 in France's public research outfits such as INSERM, France's national biomedical research agency, and the Centre National de la Recherche Scientifique (CNRS), the country's largest research agency.

Under this plan, laboratory directors will be subject to a four-yearly review and will have to compete for reappointment at the end of a 12-year period. The move will be retroactive, meaning that around half of the current directors might find themselves ousted in the next two years.

And because he believes that "researchers get too focused on their own subject matter," Kourilsky wants to divert $30 \%$ of individual laboratory funds to create a common pool of money for inter-laboratory collaboration projects.

A strategy aimed at bringing young blood into the institute-the Pasteur, along with France's other major research agencies, will lose roughly half its scientists to retirement in the next five to ten years-is the creation of smaller laboratories steered by younger researchers for a five-year period. This is also a move to lure back scientists who have sought refuge abroad from the rigid and hierarchical structure that still governs French research.

Most scientists at the Pasteur so far have welcomed the new policies. "Everyone says we're still good, but we need to modernize," says Simon Wain-Hobson, director of a molecular retrovirology laboratory. "French science needs to change. It needs more speed, dynamism, and flexibility," he adds.

In fact, a group of Pasteur researchers hashing out reforms among themselves last year by email and other forums have been pleased that many of their suggestions have been taken up by Kourilsky, says Jean-Louis Virelizier, director of a viral immunology. "There is now reform and it is being done in a spirit of consultation and transparency that did not exist before," says Virelizier.

The reforms mirror many of those proposed by the government minister of research and technology, Claude Allègre, to modernize French research. For the last two years, Allègre has been trying to increase mobility between research agencies like INSERM and the CNRS and universities, and to recruit young scientists. These efforts, however, have engendered mostly ire from the scientific community. The last week of January saw approximately 1,000 scientists and members of scientific trade unions marching on the streets of Paris in protest at Allègre's plans.

Compared with the government's transformations, "The probability of the success with the Pasteur reforms is greater because the institute is smaller, on a single campus, has more money, and is more open minded. There's a sense of community here," Kourilsky told Nature Medicine. Heather McCabe, Paris 